\title{
Magnesium porphyrazine with peripheral methyl (3,5-dibromophenylmethyl)amino groups - synthesis and optical properties
}

\author{
Dedicated to the memory of Professor Franciszek Saczewski
}

https://doi.org/10.1515/hc-2019-0001

Received September 21, 2018; accepted December 12, 2018.

\begin{abstract}
Novel magnesium(II) porphyrazine with peripheral methyl(3,5-dibromophenylmethyl)amine groups was synthesized in a multi-step procedure starting from commercially available diaminomaleonitrile. All intermediates and the final macrocycle were characterized using UV-Vis, FT-IR, MS and various NMR techniques. The absorption and emission properties of the macrocycle were evaluated in $\mathrm{N}, \mathrm{N}$-dimethylformamide, dimethyl sulfoxide, and dichloromethane. The potential photosensitizing activity was evaluated by assessing the ability of the macrocycle to generate singlet oxygen in dimethyl sulfoxide and $N, N$-dimethylformamide.
\end{abstract}

Keywords: aminoporphyrazine; diaminomaleonitrile; Linstead macrocyclization; NMR; singlet oxygen

\section{Introduction}

In recent years, diaminomaleonitrile (DAMN) and its derivatives have been applied in the synthesis of many heterocyclic compounds, including imidazoles, pyrazines,

\footnotetext{
* Corresponding author: Tomasz Goslinski, Department of Chemical Technology of Drugs, Poznan University of Medical Sciences, Grunwaldzka 6, 60-780 Poznan, Poland, e-mail: tomasz.goslinski@ump.edu.pl Ewelina Wieczorek, Department of Chemical Technology of Drugs, Poznan University of Medical Sciences, Grunwaldzka 6, 60-780 Poznan, Poland

Jaroslaw Piskorz and Jadwiga Mielcarek, Department of Inorganic and Analytical Chemistry, Poznan University of Medical Sciences, Grunwaldzka 6, 60-780 Poznan, Poland

Lukasz Popenda and Stefan Jurga, NanoBioMedical Centre, Adam Mickiewicz University, Umultowska 85, 61-614 Poznan, Poland
}

pyrimidines, purines, azepines, pyrroles, oxazoles, nucleosides as well as porphyrazine macrocycles [1-10]. At present, after many years of research, porphyrazines (Pzs) substituted with nitrogen atoms in the $\beta$ positions or having rings bound to both $\beta, \beta$ positions form a distinct class of novel macrocycles (aminoporphyrazines), along with other porphyrazines substituted with sulphur, oxygen, alkyl or aryl residues [11-14]. Aminoporphyrazines reveal coordination properties due to the presence of metal ion binding sites in the macrocyclic core and the periphery. Due to interesting optical and electrochemical properties, they have been widely researched for many potential applications in nanotechnology, materials and medicinal chemistry $[11,15,16]$. Lately, our group has studied porphyrazines substituted in the periphery with methyl(3-pyridylmethyl)amino, 2,5-dimethylpyrrolyl substituents, dimethylamino, 2,5-dimethylpyrrol-1-yl, 2,5-dithienylpyrrol-1-yl, 2,5-di(biphenyl-4-yl)pyrrol-1-yl and 2-(1-adamantyl)-5-phenylpyrrol-1-yl moieties [17-23]. Moreover, an earlier developed alkylation path $[1,4,15]$ leading to tetraalkylated diaminomaleonitrile substrates for Pzs synthesis has been explored [6]. The reactivity of therein described dialkylated diaminomaleonitrile representative, 2,3-bis[(3-pyridylmethyl)amino]-2(Z)-butene1,4-dinitrile, has been analyzed by using X-ray and DFT studies. Tetraalkylated DAMN, 2,3-bis[methyl(3-pyridylmethyl)amino]-2(Z)-butene-1,4-dinitrile, has been applied in the synthesis of tribenzoporphyrazine with methyl(3pyridylmethyl)amino groups which was additionally subjected to solvatochromic and metallation studies.

Herein we report the synthesis and characterization of porphyrazine bearing peripheral methyl(3,5-dibromophenylmethyl)amine groups in the periphery. This study is an extension of our previous report [6] on the unusual reactivity and applications of diaminomaleonitrile in the synthesis of porphyrazine systems. The aminoporphyrazines and seco-dimethylaminoporphyrazines have been extensively 
studied as photosensitizers in the photodynamic therapy of cancer and as robust catalysts for highly efficient endoperoxide synthesis $[11,16]$. In our current study, we attempted to design a new porphyrazine which could be of potential value as a building block for novel electronic and optical materials as well as a catalyst or sensor for technology and medicine. Further studies of novel DAMN derivatives seem to be worthy due to the possibilities of the discovery of potential biologically active compounds.

\section{Results and discussion}

\section{Synthesis and characterization}

Maleonitrile derivative $\mathbf{6}$ was obtained in a multi-step procedure starting from a commercially available diaminomaleonitrile (1) adapting the conditions reported by Begland et al. [1], Beall et al. [15] and Fuchter et al. [4]. Sequential double-reductive alkylation of 1 was employed to yield the intermediate products 2-amino-3-[(3,5-dibromophenylmethylidene)amino]-2(Z)-butene-1,4-dinitrile (2), 2-amino-3-[(3,5-dibromophenylmethyl)amino]-2(Z)butene-1,4-dinitrile (3), 2-[(3,5-dibromophenylmethyl)
amino]-3-[(3,5-dibromophenylmethylidene)amino]-2(Z)butene-1,4-dinitrile (4) and 2,3-bis[(3,5-dibromophenylmethyl)amino]-2(Z)-butene-1,4-dinitrile (5). Our previous study on the alkylation reaction with dimethyl sulfate of dialkylated diaminomaleonitrile substrates, indicated the prevalence of the alkylation reaction after treating dialkylated derivative as disodium salt with dimethyl sulfate at lower temperatures, whereas at higher temperatures the alkylating agent acted as a hydride anion acceptor, which favored the elimination reaction to imine 2-[(3-pyridylmethyl)amino]-3-[(3-pyridylmethylidene)amino]-2(Z)-butene1,4-dinitrile with $45 \%$ yield [6]. To avoid this unwelcome process in our study, the alkylation reaction of dialkylated derivative 5 to tetralkylated derivative $\mathbf{6}$ was performed in DMF with methyl iodide (in the presence of cesium carbonate as a base at $40^{\circ} \mathrm{C}$ for $24 \mathrm{~h}$ ) by adapting the procedure of Fuchter et al. [4]. Maleonitrile 6 was used in the Linstead macrocyclization reaction [26] with magnesium $n$-butanolate in $n$-butanol to give porphyrazine 7 in moderate $37 \%$ overall yield (Scheme 1).

The structural analysis of porphyrazine 7 was undertaken using $1 \mathrm{D}^{1} \mathrm{H}$ and ${ }^{13} \mathrm{C}$ NMR and a range of $2 \mathrm{D}$ NMR experiments (COSY, HSQC and HMBC). Detailed analysis of NMR spectra is presented in Figure 1 and in Table 1. The ${ }^{1} \mathrm{H}-{ }^{-1} \mathrm{H}$<smiles>CC(C)(C)C#N</smiles>

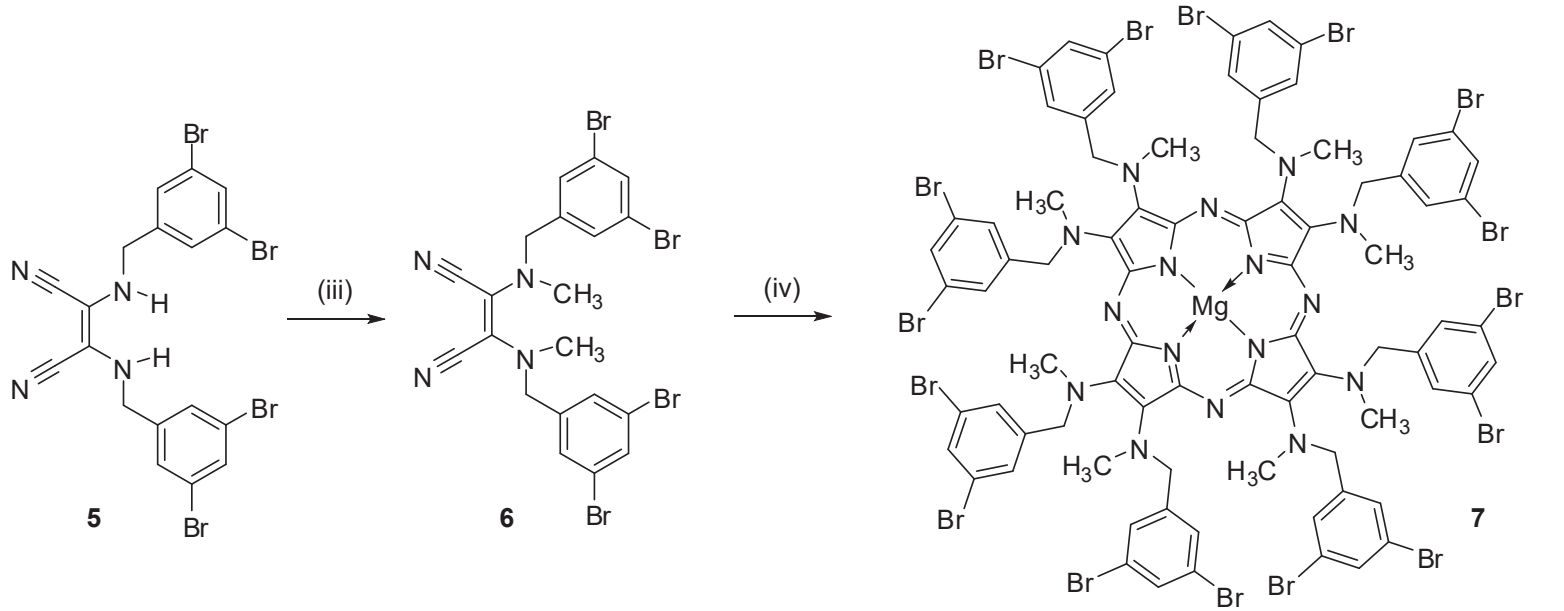

Scheme 1 Reagents and conditions: (i) 3,5-dibromobenzaldehyde, methanol, TFA, rt, 30 min; (ii) sodium borohydride, methanol, rt, 30 min; (iii) methyl iodide, DMF, cesium carbonate, $40^{\circ} \mathrm{C}, 24 \mathrm{~h}$; (iv) $\mathrm{Mg}(\mathrm{O}-n \mathrm{Bu})_{2}, n \mathrm{BuOH}$, reflux, $20 \mathrm{~h}$ 


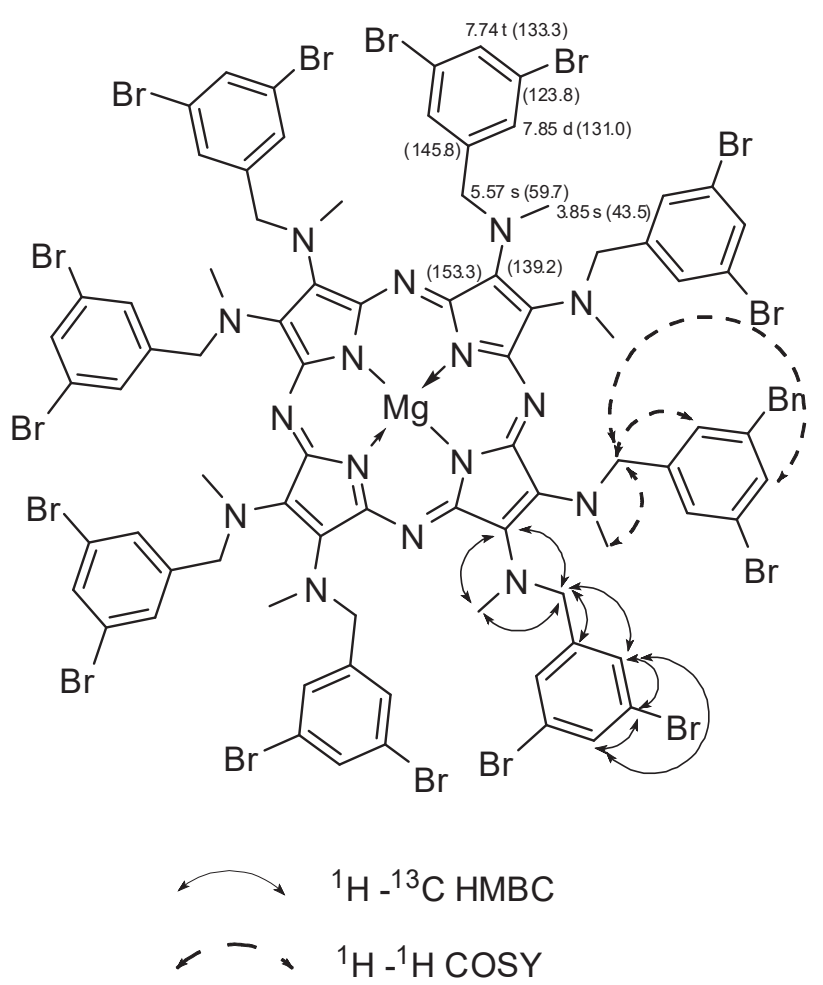

Figure 1 NMR data of 7: ${ }^{1} \mathrm{H}$ and $\left({ }^{13} \mathrm{C}\right)$ chemical shift values and key correlations observed in NMR spectra. Dotted lines: ${ }^{1} \mathrm{H}-{ }^{1} \mathrm{H}$ COSY; Continuous arrows: ${ }^{1} \mathrm{H}-{ }^{13} \mathrm{C}$ HMBC.

Table $1^{1} \mathrm{H}$ and ${ }^{13} \mathrm{C}$ NMR data obtained for 7 including key correlations determined from ${ }^{1} \mathrm{H}-{ }^{13} \mathrm{C}$ HSQC and ${ }^{1} \mathrm{H}-{ }^{13} \mathrm{C}$ HMBC spectra.

\begin{tabular}{|c|c|c|c|c|c|c|}
\hline $\begin{array}{l}\delta_{H} \\
(\mathrm{ppm})\end{array}$ & $\begin{array}{c}\text { Multiplicity } \\
\left.\mathrm{U}_{\mathrm{H}-\mathrm{H}} \text { in } \mathrm{Hz}\right)\end{array}$ & $\begin{array}{c}{ }^{1} \mathrm{H}-{ }^{13} \mathrm{C} \\
\mathrm{HSQC} \\
\delta(\mathrm{ppm})\end{array}$ & & $\begin{array}{r}{ }^{1} \mathrm{H}-{ }^{13} \mathrm{CH} \\
\quad \delta(\mathrm{pp}\end{array}$ & $\begin{array}{l}\text { HMBC } \\
\text { om) }\end{array}$ & $\begin{array}{c}{ }^{1} \mathrm{H}-{ }^{1} \mathrm{H} \\
\mathrm{COSY} \\
\delta(\mathrm{ppm})\end{array}$ \\
\hline 3.85 & $\mathrm{~s}$ & 43.5 & 139.2 & 59.7 & & 5.57 \\
\hline 5.57 & $\mathrm{~s}$ & 59.7 & 145.8 & 139.2 & $131.0 \quad 43.5$ & 7.853 .85 \\
\hline 7.74 & $t(2)$ & 133.3 & 131.0 & 123.8 & & 5.57 \\
\hline 7.85 & $d(2)$ & 131.0 & 133.3 & 123.8 & 59.7 & 5.57 \\
\hline
\end{tabular}

Quaternary carbon atoms: 123.8, 139.2, 145.8, 153.3 ppm

COSY and ${ }^{1} \mathrm{H}^{-13} \mathrm{C}$ HMBC experiments turned out particularly useful to elucidate the structure of porphyrazine 7 . The signals at $5.57 \mathrm{ppm}$ were assigned to $\mathrm{NCH}_{2}$ hydrogen atoms of methyl(3,5-dibromophenylmethyl)amino substituent due to the long-range correlations to protons at C2' (7.85 ppm) and C4' (7.74 ppm) of the 3,5-dibromophenyl fragment via ${ }^{4} \mathrm{~J}$ and ${ }^{6} \mathrm{~J}$ couplings, respectively, and correlations to the macrocyclic core C2, C3 carbons at $139.2 \mathrm{ppm}$. Other useful correlations within the methyl(3,5-dibromophenylmethyl) amino group were observed interchangeably between $\mathrm{NCH}_{2}$ at $5.57 \mathrm{ppm} / 59.7 \mathrm{ppm}$ and $\mathrm{NCH}_{3}$ at $3.85 \mathrm{ppm} / 43.5 \mathrm{ppm}$ protons/carbons, respectively. The ${ }^{1} \mathrm{H}^{-1} \mathrm{H}$ COSY spectra

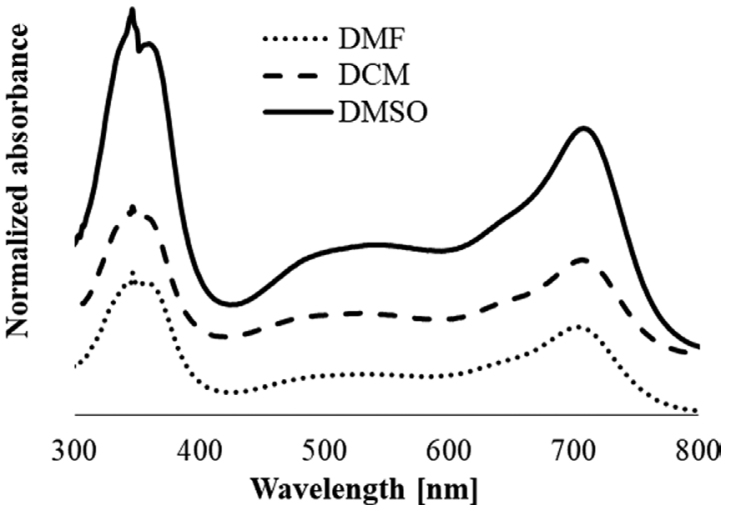

Figure 2 Normalized absorption spectra of 7 in selected organic solvents.

of 7 revealed substantial cross-ring long-range coupling between $\mathrm{H}-2 / \mathrm{H}-6$ and $\mathrm{H}-4$ within methyl(3,5-dibromophenylmethyl)amino group, which were confirmed by ${ }^{4} \mathrm{~J}$ proton-proton meta-coupling of $2 \mathrm{~Hz}$ in the ${ }^{1} \mathrm{H}$ NMR.

HPLC analysis confirmed the purity of the macrocyclic compound 7 at a level above 95\% (see Supplementary Information).

\section{Optical studies}

The electronic absorption spectra of porphyrazine 7 were recorded in dimethylformamide (DMF), dimethylsulfoxide (DMSO) and dichloromethane (DCM) (Figure 2). Two characteristic bands, a broad intense Soret band with maximum absorption at $346 \mathrm{~nm}$ and a Q-band with $\lambda_{\max }$ in the range of 704-708 $\mathrm{nm}$ are observed. Also, in the UV-Vis spectra recorded in all solvents a wide, flat absorption band at about $500-550 \mathrm{~nm}$ is present. The $n-\pi^{\star}$ transitions are the result of the donation of a lone pair of electrons present on the external nitrogens to the macrocyclic ring [11]. Emission measurements carried out in both DMF and DMSO solutions do not indicate the ability of 7 to fluorescence.

The potential photosensitizing activity of 7 was determined by measuring its ability to generate singlet oxygen as a result of the interaction between the activated photosensitizer and triplet oxygen. DPBF was used as a chemical quencher, which undergoes a cycloaddition reaction with singlet oxygen to produce endoperoxide. Solutions containing 7 or $\mathrm{ZnPc}$ (as a reference) in a mixture with DPBF in DMF or DMSO were irradiated with monochromatic light of wavelengths adjusted to the Q-band maxima [14, 27]. In DMF, upon interaction with singlet oxygen, DPBF is oxidized and decomposed which is manifested in the UV-Vis spectrum as a decrease in the absorbance at $417 \mathrm{~nm}$ (Figure 3a). However, the calculated singlet oxygen quantum yield $\left(\Phi_{\Delta}\right)$ is low 


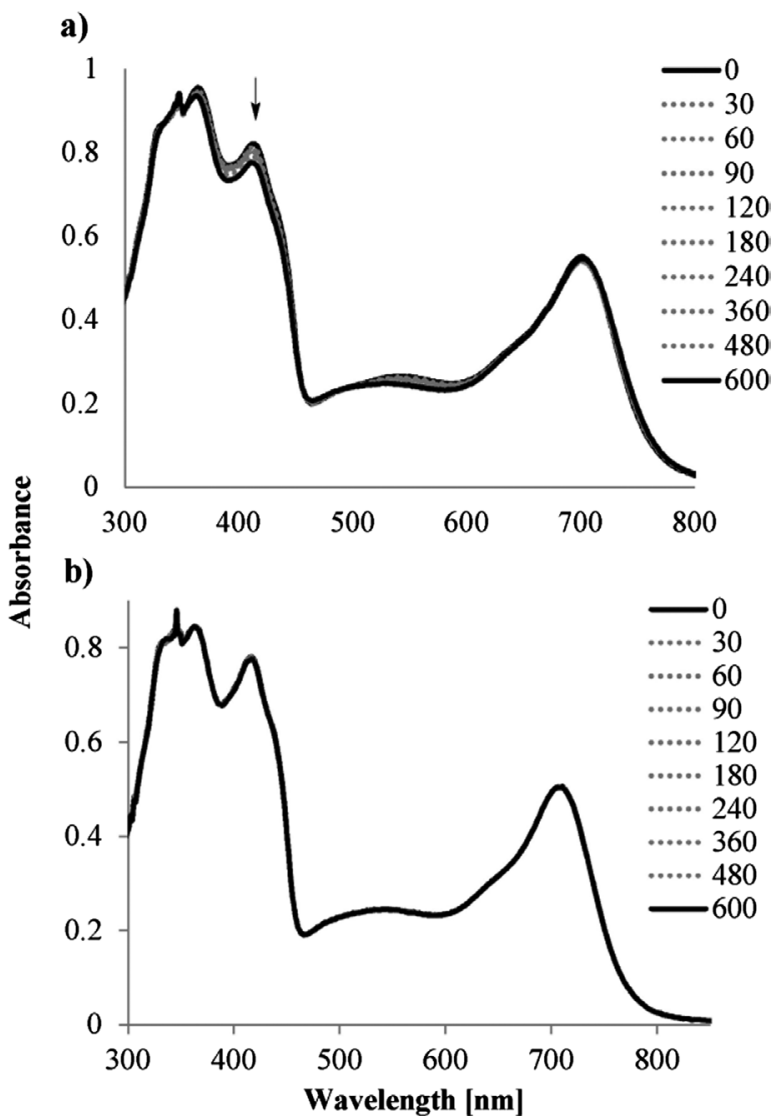

Figure 3 Changes in the UV-Vis spectra during irradiation of 7 and DPBF in DMF (a) and DMSO (b).

and does not exceed the value of 0.01 . When DMSO is used as a solvent, no significant changes in the UV-Vis absorption spectra of porphyrazine are observed, upon exposure to radiation (Fig. 3b). The facts that the fluorescence emission is not observed as well as the values of singlet oxygen generation are very low, indicate that both fluorescence is not the main radiative deactivation pathway to the ground state as well as the triplet state population is not significant enough. It is known that the more significant the population of the first triplet state is, the higher the probability of the energy transfer from the photosensitizer to the oxygen with the consequent production of singlet oxygen is observed [28]. Usually, the presence of heavy atoms, such as bromine atoms, increases the efficiency of intersystem crossing to the triplet state and yields of singlet oxygen generation. In the studied process another independent pathway for the deactivation of sensitized excited states that competes with energy transfer to $\mathrm{O}_{2}$ seems to take place. Possibly, vibrational relaxation which is a nonradiative deactivation process to the ground state mediated by the collisions between the chromophore and its surrounding environment cannot be excluded following the Jablonski diagram. Such molecules can be further studied regarding photoacoustic imaging/spectroscopy [29].

\section{Conclusions}

Novel magnesium(II) porphyrazine with peripheral methyl(3,5-dibromophenylmethyl)amine groups was synthesized in a multi-step procedure starting from commercially available diaminomaleonitrile. All intermediates and the final macrocycle were characterized using UVVis, FT-IR, MS MALDI, and various NMR techniques. Also, the optical absorption and emission properties of novel macrocycle were studied. The potential photosensitizing activity of the macrocycle was evaluated by measuring its ability to generate singlet oxygen. Lack of fluorescence and very low values of singlet oxygen generation efficiency below $1 \%$ in dimethyl sulfoxide and dimethylformamide indicate the participation of other processes following the Jablonski diagram. The interpretation of the results could take into account the deactivation of sensitized excited states competing with the relaxation of a molecule. It could result in the emission of a photon (fluorescence), and an energy transfer via intersystem crossing to $\mathrm{O}_{2}$. The vibrational relaxation which is a nonradiative deactivation process to the ground state mediated by the collisions between the chromophore and its surrounding environment cannot be excluded. Nevertheless, in such case very advanced photoacoustic imaging/spectroscopy processes should be studied to check the potential utility of a novel molecule in light-based thermal therapies. Another possible application of the novel molecule concerns catalysis, analytical and materials chemistry. For example Ivanova et al. have so far performed a study on structurally similar octa(4-bromophenyl)porphyrazine indicating its complexation properties with $\mathrm{Cd}^{2+}$ cations in DMSO at $298 \mathrm{~K}$ [30].

\section{Experimental}

All reactions were conducted in oven-dried glassware under argon using a Radleys Heat-On heating system. Solvents and all reagents were obtained from commercial suppliers and used without further purification. All solvents were removed by rotary evaporation at or below $50 \stackrel{\circ}{\circ}$. Dry flash column chromatography was carried out on Merck silica gel 60 , particle size $40-63 \mu \mathrm{m}$, reverse phase Fluka C18 silica gel 90. Thin layer chromatography (TLC) was performed on silica gel Merck Kieselgel $60 \mathrm{~F}_{254}$ plates and Merck Kieselgel RP-18 $60 \mathrm{~F}_{254} \mathrm{~s}$ visualized with $\mathrm{UV}\left(\lambda_{\max } 254\right.$ or $\left.365 \mathrm{~nm}\right)$. UV-Vis spectra were recorded on a 
Hitachi UV/VIS U-1900 and Shimadzu PC-160 spectrophotometers. FT-IR spectra were recorded using IRAffinity-1 spectrometer (Shimadzu, Japan) in KBr pellets. Melting points were obtained on a Stuart Bibby apparatus and are uncorrected. ${ }^{1} \mathrm{H}$ and ${ }^{13} \mathrm{C}$ NMR spectra were acquired on an Agilent DD2 800 spectrometer at $298 \mathrm{~K}$. The ${ }^{1} \mathrm{H}$ and ${ }^{13} \mathrm{C}$ resonances were unambiguously assigned based on ${ }^{1} \mathrm{H},{ }^{13} \mathrm{C},{ }^{1} \mathrm{H}-{ }^{-1} \mathrm{H}$ COSY, ${ }^{1} \mathrm{H}^{-13} \mathrm{C} \mathrm{HSQC}$, and ${ }^{1} \mathrm{H}^{-13} \mathrm{C}$ HMBC experiments. Mass spectra (MS ES, HRMS ES, MALDI TOF) were carried out by the Advanced Chemical Equipment and Instrumentation Facility at the Faculty of Chemistry and the Wielkopolska Center for Advanced Technologies at Adam Mickiewicz University in Poznan.

\section{2-Amino-3-[(3,5-dibromophenylmethylidene)amino]- 2(Z)-butene-1,4-dinitrile (2)}

Diaminomaleonitrile (1.00 g, $9.25 \mathrm{mmol})$ and 3,5-dibromobenzaldehyde $(2.44 \mathrm{~g}, 9.25 \mathrm{mmol})$ were dissolved in methanol $(35 \mathrm{~mL})$ and the solution was treated with a catalytic amount of trifluoroacetic acid. When the yellow solid appeared after $30 \mathrm{~min}$, the mixture was filtered to give yellow product 2; yield $2.38 \mathrm{~g}(86 \%)$; $\mathrm{mp}$ 209-211 ${ }^{\circ} \mathrm{C} ; \mathrm{R}_{f}\left(\mathrm{CH}_{2} \mathrm{Cl}_{2}\right)$ 0.43; UV-Vis $\left(\mathrm{CH}_{2} \mathrm{Cl}_{2}\right): \lambda_{\max }, \mathrm{nm}$ (loge) 363 (4.45), 264 (4.51), 233 (4.30); IR: v 3328, 2210, 1617, 1378, $975 \mathrm{~cm}^{-1} ;{ }^{1} \mathrm{H}$ NMR (DMSO- $\left.d_{6}\right): \delta_{\mathrm{H}}, \mathrm{ppm} 7.89(\mathrm{t}$, $\left.{ }^{4} \mathrm{~J}=2 \mathrm{~Hz}, 1 \mathrm{H}, \mathrm{C} 3-\mathrm{ArH}\right), 8.20(\mathrm{~s}, 1 \mathrm{H}, \mathrm{N}=\mathrm{C}-\mathrm{H}), 8.27$ (s, 2H, $\left.\mathrm{NH}_{2}\right), 8.30\left(\mathrm{~d},{ }^{4} \mathrm{~J}=2 \mathrm{~Hz}, 2 \mathrm{H}, \mathrm{C1}-\mathrm{ArH}\right) ;{ }^{13} \mathrm{C}$ NMR (DMSO- $\left.d_{6}\right)$ : $\delta_{\mathrm{C}} 151.6,139.4,135.3,130.3,128.3,122.9,114.1,113.5,101.7$. ESI-HRMS. Calcd for $\mathrm{C}_{11} \mathrm{H}_{7} \mathrm{Br}_{2} \mathrm{~N}_{4},[\mathrm{M}+\mathrm{H}]^{+}: \mathrm{m} / z 352.9032$. Found: $m / z$ 352.9025.

\section{2-Amino-3-[(3,5-dibromophenylmethyl)amino]-2(Z)- butene-1,4-dinitrile (3)}

Compound $2(1.00 \mathrm{~g}, 2.45 \mathrm{mmol})$ was suspended in methanol $(60 \mathrm{~mL})$. Next, sodium borohydride $(0.37 \mathrm{~g}, 9.8 \mathrm{mmol})$ was added in a few portions until the solid dissolved, and the mixture was stirred for $15 \mathrm{~min}$ at room temperature. Then, the mixture was poured on crushed ice with water and the resultant yellow solid precipitate was filtered and purified via column chromatography $\left(\mathrm{CH}_{2} \mathrm{Cl}_{2}: \mathrm{CH}_{3} \mathrm{OH}, 50: 1\right)$ to give yellow solid; yield $2.62 \mathrm{~g}(95 \%) ; \mathrm{mp} 194-196^{\circ} \mathrm{C} ; \mathrm{R}_{f}$ $\left(\mathrm{CH}_{2} \mathrm{Cl}_{2}\right)$ 0.21. UV-Vis $\left(\mathrm{CH}_{2} \mathrm{Cl}_{2}\right): \lambda_{\max }, \mathrm{nm}(\log \varepsilon) 304(4.35), 231$ (4.16); IR: $v$ 3336, 2209, 1560, 1368, 1252, $844 \mathrm{~cm}^{-1}$; ${ }^{1} \mathrm{H}$ NMR $\left(\right.$ DMSO- $\left.d_{6}\right): \delta_{\mathrm{H}} 4.22\left(\mathrm{~d},{ }^{3} \mathrm{~J}=6 \mathrm{~Hz}, 2 \mathrm{H}, \mathrm{CH}_{2}\right), 5.61\left(\mathrm{t},{ }^{3} \mathrm{~J}=6 \mathrm{~Hz}\right.$, $1 \mathrm{H}, \mathrm{NH}), 5.83\left(\mathrm{~s}, 2 \mathrm{H}, \mathrm{NH}_{2}\right), 7.53$ (d, $\left.{ }^{4} \mathrm{~J}=2 \mathrm{~Hz}, 2 \mathrm{H}, \mathrm{C1}-\mathrm{ArH}\right), 7.75$ (t, $\left.{ }^{4} \mathrm{~J}=2 \mathrm{~Hz}, 1 \mathrm{H}, \mathrm{C} 3-\mathrm{ArH}\right) ;{ }^{13} \mathrm{C}$ NMR (DMSO- $\left.d_{6}\right): \delta_{\mathrm{C}} 144.2,132.1$, 129.2, 122.5, 116.3, 115.6, 106.4, 109.9, 47.7. ESI-HRMS. Calcd for $\mathrm{C}_{11} \mathrm{H}_{9} \mathrm{Br}_{2} \mathrm{~N}_{4},[\mathrm{M}+\mathrm{H}]^{+}: m / z$ 354.9188. Found: $m / z 354.9173$.

\section{2-[(3,5-Dibromophenylmethyl)amino]-3-[(3,5-dibromo- phenylmethylidene)amino]-2(Z)-butene-1,4-dinitrile (4)}

A solution of 4 ( $2.50 \mathrm{~g}, 7.00 \mathrm{mmol})$ and 3,5-dibromobenzaldehyde $(2.20 \mathrm{~g}, 8.40 \mathrm{mmol})$ in methanol $(60 \mathrm{~mL})$ was treated with a catalytic amount of trifluoroacetic acid. When the yellow solid precipitated after $30 \mathrm{~min}$, the mixture was filtered off to give a yellow solid of 4; yield $2.31 \mathrm{~g}(55 \%)$; mp $185-187^{\circ} \mathrm{C} ; \mathrm{R}_{f}\left(\mathrm{CH}_{2} \mathrm{Cl}_{2}\right)$ 0.73. UV-Vis $\left(\mathrm{CH}_{2} \mathrm{Cl}_{2}\right)$ : $\lambda_{\max }, \mathrm{nm}(\log \varepsilon) 383$ (4.47), 268 (4.22), 233 (4.31); IR: v 3067, 2190, 1560, 1240, $951 \mathrm{~cm}^{-1}$; ${ }^{1} \mathrm{H}$ NMR (DMSO- $\left.d_{6}\right): \delta_{\mathrm{H}} 4.66\left(\mathrm{~d},{ }^{3} \mathrm{~J}\right.$ $\left.=5 \mathrm{~Hz}, 2 \mathrm{H}, \mathrm{CH}_{2}\right), 7.60\left(\mathrm{~d}^{4} \mathrm{~J}=2 \mathrm{~Hz}, 2 \mathrm{H}, \mathrm{CH}_{2}-\mathrm{C} 1-\mathrm{ArH}\right), 7.79(\mathrm{t}$, $\left.{ }^{4} \mathrm{~J}=2 \mathrm{~Hz}, 1 \mathrm{H}, \mathrm{N}=\mathrm{CH}-\mathrm{C} 3-\mathrm{ArH}\right), 7.93\left(\mathrm{t},{ }^{4} \mathrm{~J}=2 \mathrm{~Hz}, 1 \mathrm{H}, \mathrm{CH}_{2}-\mathrm{C} 3\right.$ $\operatorname{ArH}), 7.99\left(\mathrm{~d},{ }^{4} \mathrm{~J}=2 \mathrm{~Hz}, 1 \mathrm{H}, \mathrm{NH}\right), 8.28(\mathrm{~s}, 2 \mathrm{H}, \mathrm{N}=\mathrm{CH}-\mathrm{C} 1 \mathrm{ArH})$, $8.84(\mathrm{~s}, 1 \mathrm{H}, \mathrm{N}=\mathrm{CH}) ;{ }^{13} \mathrm{C}$ NMR (DMSO- $\left.d_{6}\right): \delta_{\mathrm{C}} 153.0,142.9$, 139.2, 135.6, 132.5, 130.4, 129.5, 129.1, 123.0, 122.7, 122.6, 113.4, 103.3, 48.0. ESI-HRMS. Calcd for $\mathrm{C}_{18} \mathrm{H}_{11} \mathrm{Br}_{4} \mathrm{~N}_{4}$, $[\mathrm{M}+\mathrm{H}]^{+}$: $m / z$ 598.7711. Found: $m / z 598.7709$.

\section{2,3-Bis[(3,5-dibromophenylmethyl)amino]-2(Z)-butene- 1,4-dinitrile (5)}

A suspension of $4(2.00 \mathrm{~g}, 3.30 \mathrm{mmol})$ in methanol $(100$ $\mathrm{mL})$ was treated with sodium borohydride $(0.50 \mathrm{~g}, 13.3$ mmol) in few portions until the solid dissolved and the mixture was stirred for $15 \mathrm{~min}$ at room temperature. Then, the mixture was poured on crushed ice with water and the resultant yellow solid was filtered and purified via column chromatography $\left(\mathrm{CH}_{2} \mathrm{Cl}_{2}: \mathrm{CH}_{3} \mathrm{OH}, 20: 1\right)$; yield 1.95 g (98\%); mp $210-212^{\circ} \mathrm{C} ; \mathrm{R}_{f}\left(\mathrm{CH}_{2} \mathrm{Cl}_{2}\right)$ 0.58. UV-Vis $\left(\mathrm{CH}_{2} \mathrm{Cl}_{2}\right)$ : $\lambda_{\max }, \mathrm{nm}(\log \varepsilon) 382$ (4.43), 268 (4.18), 233 (4.40); IR: v 3067, 2923, 2232, 1576, 1420, 1233, 854, $743 \mathrm{~cm}^{-1}$; ' ${ }^{1} \mathrm{H}$ NMR (DMSO$\left.d_{6}\right): \delta_{\mathrm{H}} 4.30\left(\mathrm{~d},{ }^{4} \mathrm{~J}=2 \mathrm{~Hz}, 4 \mathrm{H}, \mathrm{CH}_{2}\right), 6.07\left(\mathrm{t},{ }^{3} \mathrm{~J}=6 \mathrm{~Hz}, 2 \mathrm{H}\right.$, $\mathrm{NH}), 7.53\left(\mathrm{~d},{ }^{4} \mathrm{~J}=2 \mathrm{~Hz}, 4 \mathrm{H}, \mathrm{C1}-\mathrm{ArH}\right), 7.76\left(\mathrm{t},{ }^{4} \mathrm{~J}=2 \mathrm{~Hz}, 2 \mathrm{H}\right.$, C3-ArH); ${ }^{13} \mathrm{C}$ NMR (DMSO- $\left.d_{6}\right): \delta_{\mathrm{C}} 143.9,132.3,129.3,122.6$, 115.1, 109.9, 47.6. ESI-HRMS. Calcd for $\mathrm{C}_{18} \mathrm{H}_{13} \mathrm{Br}_{4} \mathrm{~N}_{4},[\mathrm{M}+\mathrm{H}]^{+}$: $\mathrm{m} / z$ 600.7868. Found: $m / z 600.7685$.

\section{2,3-Bis[methyl(3,5-dibromophenylmethyl)amino]-2(Z)- butene-1,4-dinitrile (6)}

A solution of $5(1.00 \mathrm{~g}, 1.66 \mathrm{mmol})$ and methyl iodide (0.41 $\mathrm{mL} 6.64 \mathrm{mmol}$ ) in dry DMF $(5 \mathrm{~mL})$ was added over $1 \mathrm{~h}$ to a rapidly stirring suspension of cesium carbonate $(1.62 \mathrm{~g}$, $4.97 \mathrm{mmol})$ in dry DMF (7 ml). After the addition was completed, the mixture was heated to $40^{\circ} \mathrm{C}$ and stirred for 19 h. Then, the mixture was cooled to room temperature and poured onto ice with water and extracted with $\mathrm{CH}_{2} \mathrm{Cl}_{2}$. The organic layers were combined and concentrated under reduced pressure. The residue was purified using column 
chromatography $\left(\mathrm{CH}_{2} \mathrm{Cl}_{2}: \mathrm{CH}_{3} \mathrm{OH}, 50: 1\right)$ to give 6 as a yellow solid; yield $0.84 \mathrm{~g}(79 \%) ; \mathrm{mp} 198-201^{\circ} \mathrm{C} ; \mathrm{R}_{f}\left(\mathrm{CH}_{2} \mathrm{Cl}_{2}\right)$ 0.6. UV-Vis $\left(\mathrm{CH}_{2} \mathrm{Cl}_{2}\right): \lambda_{\max }, \mathrm{nm}(\log \varepsilon) 316$ (4.13), 233 (4.24); IR: v 3337, 3071, 2921, 2185, 1560, 1424, 1201, 1103, 842, $743 \mathrm{~cm}^{-1}$; ${ }^{1} \mathrm{H}$ NMR (DMSO- $\left.d_{6}\right): \delta_{\mathrm{H}} 2.70\left(\mathrm{~s}, 6 \mathrm{H}, \mathrm{CH}_{3}\right), 4.26\left(\mathrm{~s}, 4 \mathrm{H}, \mathrm{CH}_{2}\right)$, $7.43\left(\mathrm{~d},{ }^{4} \mathrm{~J}=2 \mathrm{~Hz}, 4 \mathrm{H}, \mathrm{C} 1-\mathrm{ArH}\right), 7.76$ (t, $\left.{ }^{4} \mathrm{~J}=2 \mathrm{~Hz}, 2 \mathrm{H}, \mathrm{C} 3-\mathrm{ArH}\right)$. ${ }^{13}$ C NMR (DMSO- $d_{6}$ ): $\delta_{C} 144.3,135.7,133.1,125.7,120.0,118.0$, 59.2, 43.3. ESI-HRMS. Calcd for $\mathrm{C}_{20} \mathrm{H}_{16} \mathrm{Br}_{4} \mathrm{~N}_{4} \mathrm{Na},[\mathrm{M}+\mathrm{Na}]^{+}$: $m / z$ 654.7967. Found: $m / z$ 654.7963. ESI-HRMS. Calcd for $\mathrm{C}_{20} \mathrm{H}_{17} \mathrm{Br}_{4} \mathrm{~N}_{4},[\mathrm{M}+\mathrm{H}]^{+}: m / z$ 632.8147. Found: $\mathrm{m} / \mathrm{z} 632.8143$.

\section{$[2,3,7,8,12,13,17,18$-Octakis(methyl(3,5-dibromophenyl- methyl)amino)porphyrazinato]-magnesium(II) (7)}

A mixture of magnesium turnings $(0.024 \mathrm{~g}, 0.39 \mathrm{mmol})$, a crystal of $\mathrm{I}_{2}$, and $n$-butanol $(6 \mathrm{~mL})$ was heated under reflux for $6 \mathrm{~h}$, then cooled to room temperature, treated with the maleonitrile derivative $6(0.249 \mathrm{~g}, 0.39 \mathrm{mmol})$ and heated under reflux for an additional $20 \mathrm{~h}$. After cooling to room temperature, the dark blue mixture was filtered through Celite and concentrated. Column chromatography $\left(\mathrm{CH}_{2} \mathrm{Cl}_{2}: \mathrm{CH}_{3} \mathrm{OH}, 50: 1\right)$ of the residue furnished product 7 as a dark blue solid; yield $92 \mathrm{mg}(37 \%) ; \mathrm{mp}>300^{\circ} \mathrm{C}$; $\mathrm{R}_{f}$ $\left(\mathrm{CH}_{2} \mathrm{Cl}_{2}: \mathrm{CH}_{3} \mathrm{OH} 100: 1\right)$ 0.19. UV-Vis $\left(\mathrm{CH}_{2} \mathrm{Cl}_{2}\right): \lambda_{\max }, \mathrm{nm}(\log \varepsilon)$ 343 (5.04), 529 (4.53), 707 (4.87); IR: v 3066, 2923, 1558, 1419, 1066, 845, $740 \mathrm{~cm}^{-1}$; ${ }^{1} \mathrm{H}$ NMR (pyridine- $d_{5}$ ): $\delta_{\mathrm{H}} 3.85$ (s, 24H, N( $\left.\left.\mathrm{CH}_{3}\right)_{2}\right), 5.57\left(\mathrm{~s}, 16 \mathrm{H}, \mathrm{CH}_{2}\right), 7.74\left(\mathrm{t},{ }^{4} \mathrm{~J}=2 \mathrm{~Hz}, 8 \mathrm{H}\right.$, C3-ArH), 7.85 (d, ${ }^{4} \mathrm{~J}=2 \mathrm{~Hz}, 16 \mathrm{H}, \mathrm{C1}-\mathrm{ArH}$ ); ${ }^{13} \mathrm{C}$ NMR (pyridine$\left.d_{5}\right): \delta_{\mathrm{C}} 153.3,145.8,139.2,133.3,131.0,123.8$ hidden, 59.7, 43.5. MS (MALDI). Calcd for $\mathrm{C}_{80} \mathrm{H}_{65} \mathrm{Br}_{16} \mathrm{MgN}_{16},[\mathrm{M}+\mathrm{H}]^{+}: \mathrm{m} / z$ 2536.2363. Found: $m / z 2536.2368$. HPLC purity is over $95 \%$ (see supplementary information).

\section{Optical studies}

All experiments have been performed at ambient temperature. UV-Vis spectra were recorded in the range of 200-900 nm using Shimadzu UV-160A and Jasco V-530 spectrophotometers. The quantum yields of singlet oxygen generation were determined in DMSO and DMF solutions ( $3.0 \mathrm{~mL}$, no oxygen bubbled) using the relative method with zinc(II) phthalocyanine (ZnPc, Sigma-Aldrich) as a reference and 1,3-diphenylisobenzofuran (DPBF) as a chemical quencher according to the previously described procedure [24]. Solutions of 7 in DMF or DMSO (absorbance of the sensitizer $\sim 0.5)$ in the presence of DPBF were irradiated in a 1-cm path-length quartz cell $(3 \mathrm{~mL})$ with monochromatic light by a $150 \mathrm{~W}$ high-pressure Xe lamp (Optel) through a monochromator M250/1200/U. The ZnPc solution was prepared analogously. The concentration of DPBF was set at $\sim 3 \times 10^{-5} \mathrm{~mol} \mathrm{~L}^{-1}$ to avoid chain reactions induced by DPBF in the presence of singlet oxygen [25]. Light of two different wavelengths adjusted to the maximum of the Q-band region was used. The light intensity was set to $0.5 \mathrm{~mW} /$ $\mathrm{cm}^{2}$ (Radiometer RD 0.2/2 with TD probe, Optel). Fluorescence measurements were performed using a Jasco 6200 spectrofluorometer.

Acknowledgment: This study was supported by the National Science Centre, Poland, under Grant No. 2012/05/E/ NZ7/01204.

\section{References}

[1] Begland, R. W.; Hartter, D. R.; Jones, F. N.; Sam D. J.; Sheppard, W. A.; Webster, O. W.; Weigert, F. J. Hydrogen cyanide chemistry. VIII. New chemistry of diaminomaleonitrile. Heterocyclic synthesis. J. Org. Chem. 1974, 39, 2341-2350.

[2] Ohtsuka, Y. Chemistry of Diaminomaleonitrile. II. Preparation of the Open-Chain Adduct with Ketone in Phosphorus Pentoxide-Ethanol System. J. Org. Chem. 1976, 41, 629-633.

[3] Al-Azmi, A.; Elassar, A. Z. A.; Booth, B. L.; The chemistry of diaminomaleonitrile and its utility in heterocyclic synthesis. Tetrahedron 2003, 59, 2749-2763.

[4] Fuchter, M. J.; Beall, L. S.; Baum, S. M.; Montalban, A. G.; Sakellariou, E. G.; Mani, N. S.; Miller, T.; Vesper, B. J.; White, A. J. P.; Williams, D. J.; Barrett, A. G. M.; Hoffman, B. M. Synthesis of porphyrazine-octaamine, hexamine and diamine derivatives. Tetrahedron 2005, 61, 6115-6130.

[5] Goslinski, T.; Zhong, C.; Fuchter, M. J.; Stern, C. L.; White, A. J. P.; Barrett, A. G. M.; Hoffman, B. M. Porphyrazines as molecular scaffolds: Flexible syntheses of novel multimetallic complexes. Inorg. Chem. 2006, 45, 3686-3694.

[6] Goslinski, T.; Dutkiewicz, Z.; Kryjewski, M.; Tykarska, E.; Sobotta, L.; Szczolko, W.; Gdaniec, M.; Mielcarek, J. Experimental and computational study on the reactivity of 2,3-bis[(3-pyridylmethyl)amino]-2(Z)-butene-1,4-dinitrile, a key intermediate for the synthesis of tribenzoporphyrazine bearing peripheral methyl(3-pyridylmethyl)amino substituents. Monats.Chem. 2011, 142, 599-608.

[7] Zare, N.; Zabardasti, A.; Dusek, M.; Eigner, V. New asymmetric and symmetric 2-((pyridin-4-yl)methylenamino)-3aminomaleo nitrile and 2,3-bis((pyridin-4-yl)methylenamino)maleonitrile Schiff bases: Synthesis, experimental characterization along with theoretical studies. J. Mol. Struct. 2011, 1163, 388-396.

[8] Kubota, Y.; Shibata, T.; Babamoto-Horiguchi, E.; Uehara, J.; Funabiki, K.; Matsumoto, S.; Ebihara, M.; Matsui, M. Reaction of 2,3-diaminomaleonitrile with diones. Tetrahedron 2009, 65, 2506-2511.

[9] Szady-Chełmieniecka, A.; Kołodziej, B.; Morawiak, M.; Kamieński, B.; Schilf, W. Spectroscopic studies of the intramolecular hydrogen bonding in o-hydroxy Schiff bases, derived from diaminomaleonitrile, and their deprotonation reaction products. Spectrochim. Acta A 2018, 189, 330-341. 
[10] Wieczorek, E.; Gierszewski, M.; Popenda, L.; Tykarska, E.; Gdaniec, M.; Jurga, S.; Sikorski, M.; Mielcarek, J.; Piskorz, J.; Goslinski, T. Synthesis, characterization and photophysical properties of novel 5,7-disubstituted-1,4-diazepine-2,3-dicarbonitriles. J. Mol. Struct. 2016, 1110, 208-214

[11] Michel, S. L. J.; Baum, S. M.; Barrett, A. G. M.; Hoffman, B. M. In Progress in Inorganic Chemistry; Karlin, K. D., Ed. J. Wiley \& Sons: New York, 2001; Vol. 50, pp 473-590.

[12] Fuchter, M. J.; Zhong, C.; Zong H.; Hoffman, B. M.; Barrett, A. G. M. Porphyrazines: Designer Macrocycles by Peripheral Substituent Change. Aust. J. Chem. 2008, 61, 235-255.

[13] Wieczorek, E.; Piskorz, J.; Popenda, L.; Jurga, S.; Mielcarek, J.; Gośliński, T. First example of a diazepinoporphyrazine with dendrimeric substituents. Tetrahedron Lett. 2017, 58, 758-761.

[14] Wieczorek, E.; Mlynarczyk, D. T.; Kucinska, M.; Dlugaszewska, J.; Piskorz, J.; Popenda, L.; Szczolko, W.; Jurga, S.; Murias, M.; Mielcarek, J.; Goslinski, T. Photophysical properties and photocytotoxicity of free and liposome entrapped diazepinoporphyrazines on $\mathrm{LNCaP}$ cells under normoxic and hypoxic conditions. Eur. J. Med. Chem. 2018, 150, 64-73.

[15] Beall, L. S.; Mani, N. S.; White, A. J. P.; Williams, D. J.; Barrett, A .G. M.; Hoffman, B. M. Porphyrazines and Norphthalocyanines Bearing Nitrogen Donor Pockets: Metal Sensor Properties. J. Org. Chem. 1998, 63, 5806-5817.

[16] Rodriguez-Morgade, M. S.; Stuzhin, P. A. The chemistry of porphyrazines: an overview J. Porphyrins Phthalocyanines, 2004, 8, 1129-1165.

[17] Goslinski, T.; Tykarska, E.; Szczolko, W.; Osmalek, T.; Smigielska, A.; Walorczyk, S.; Zong, H.; Gdaniec, M.; Hoffman, B. M.; Mielcarek, J.; Sobiak, S.; Synthesis and characterization of periphery-functionalized porphyrazines containing mixed pyrrolyl and pyridylmethylamino groups. J. Porphyrins Phthalocyanines 2009, 13, 223-234.

[18] Szczolko, W.; Sobotta, L.; Fita, P.; Koczorowski, T.; Mikus, M.; Gdaniec, M.; Orzechowska, A.; Burda, K.; Sobiak, S.; Wierzchowski, M.; Mielcarek, J.; Tykarska, E.; Goslinski, T. Synthesis, characteristics and photochemical studies of novel porphyrazines possessing peripheral 2,5-dimethylpyrrol1-yl and dimethylamino groups. Tetrahedron Lett. 2012, 53, 2040-2044.

[19] Sobotta, L.; Fita, P.; Szczolko, W.; Wrotynski, M.; Wierzchowski, M.; Goslinski, T.; Mielcarek, M. Functional singlet oxygen generators based on porphyrazines with peripheral 2,5-dimethylpyrrol-1-yl and dimethylamino groups. J. Photochem. Photobiol. A 2013, 269, 9-16.

[20] Goslinski, T.; White, A. J. P. Synthesis, characterization and spectroscopic properties of novel periphery e functionalized unsymmetrical porphyrazines containing mixed dithienylpyrrolyl and dimethylamino groups. Polyhedron 2009, 28, 2579-2584.

[21] Koczorowski. T.; Szczolko, W.; Burda, K.; Nowak, M.; Dawidowska, M.; Teubert, A.; Sobotta, L.; Gdaniec, M.; Korecki, J.; Mielcarek, J.; Tykarska, E.; Goslinski, T. Influence of bulky pyrrolyl substitent on the physicochemical properties of porphyrazines. Dyes Pigm. 2015, 112, 138-144.

[22] Kryjewski, M.; Tykarska, E.; Rebis, T.; Dlugaszewska, J.; Ratajczak, M.; Teubert, A.; Gapinski, J.; Patkowski, A.; Piskorz, J.; Milczarek, G.; Gdaniec, M.; Goslinski, T.; Mielcarek, J. Porphyrazine with bulky 2-(1-adamantyl)-5-phenylpyrrol-1-yl periphery tuning its spectral and electrochemical properties. Polyhedron 2015, 98, 217-223.

[23] Szczolko, W.; Wzgarda, A.; Koczorowski, T.; Wicher, B.; Sobotta, L.; Gdaniec, Z.; Gdaniec, M.; Mielcarek, J.; Tykarska, E.; Goslinski T. The Suzuki cross-coupling reaction for the synthesis of porphyrazine possessing bulky 2,5-(biphenyl-4-yl) pyrrol-1-yl substituents in the periphery. Polyhedron 2015, 102, 462-468.

[24] Piskorz, J.; Konopka, K.; Düzgünes, N.; Gdaniec, Z.; Mielcarek, J.; Goslinski, T. Diazepinoporphyrazines containing peripheral styryl substituents and their promising nanomolar photodynamic activity against oral cancer cells in liposomal formulations. ChemMedChem 2014, 9, 1775-1785.

[25] Durmus, M.; Ahsen, V.; Nyokong, T. Photophysical and photochemical studies of long chain-substituted zinc phthalocyanines. J. Photochem. Photobiol. A 2007, 186, 323-329.

[26] Linstead, R. P.; Whalley, M. Conjugated macrocycles. Part XXII. Tetrazaporphin and its metallic derivatives. J. Chem. Soc. 1952, 4839-4846.

[27] Seotsanyana-Mokhosi, I.; Kuznetsova, N.; Nyokong, T. Photochemical studies of tetra-2, 3-pyridinoporphyrazines. J. Photochem. Photobiol., A 2001, 140, 215-222.

[28] Oliveira, A. S.; Licsandru, D.; Boscencu, R.; Socoteanu, R.; Nacea, V.; Vieira Ferreira, L. F. A Singlet Oxygen Photogeneration and Luminescence Study of Unsymmetrically Substituted Mesoporphyrinic Compounds. Int. J. Photoenergy 2009, Article ID 413915, 10 pages.

[29] Ng, K. K.; Zheng, G. Molecular Interactions in Organic Nanoparticles for Phototheranostic Applications. Chem. Rev. 2015, 115, 11012-11042.

[30] Ivanova, Yu. B.; Sheinin, V. B.; Chizhova, N. V. Study of Acidic and Complexing Properties of Tetraphenylporphyrazine and Octa(4-Bromophenyl)porphyrazine in DMSO at 298 K. Russ. J. Coord. Chem 2006, 32, 639-643. 